\title{
Highly Polysialylated Neural Cell Adhesion Molecule (NCAM-H) Is Expressed by Newly Generated Granule Cells in the Dentate Gyrus of the Adult Rat
}

\author{
Tatsunori Seki and Yasumasa Arai \\ Department of Anatomy, Juntendo University School of Medicine, Tokyo 113, Japan
}

\begin{abstract}
We have found in the adult rat that the persistent expression of a highly polysialylated neural cell adhesion molecule (NCAM-H) that is generally specific to developing tissues, remains restrictively in the cells of the deepest portion of the dentate granular layer. Since the granule cells are known to continue to be generated in this region during the adult period, we have tried to determine whether NCAM-H is expressed by newly generated granule cells. Immunoelectron microscopic observation revealed that about half of the NCAM-H-expressing cells had the features of dentate granule cells, and that the rest of these cells appeared to be immature cells. Double immunostaining for NCAM-H and glial fibrillary acidic protein (GFAP) revealed that the NCAM-Hexpressing cells differed from GFAP-positive glial cells. In rats injected with 5-bromo-2'-deoxyuridine (BrdU) at postnatal day 35, double immunostaining for NCAM-H and BrdU demonstrated that the BrdU-labeled cells expressed NCAM-H at $12 \mathrm{~d}$ after the injection but not at $80 \mathrm{~d}$. These results provide the first direct evidence that NCAM-H is expressed transiently by newly generated granule cells that may add new neuronal circuits to the adult hippocampal formation.

[Key words: neural cell adhesion molecule, polysialic acid, hippocampus, dentate gyrus, neurogenesis, plasticity]
\end{abstract}

One of the distinctive features of the hippocampal formation is that the granule cells of the dentate gyrus continue to be produced after birth, and even during the adult period (Altman and Das, 1965; Kaplan and Hinds, 1977; Bayer et al., 1982; Boss et al., 1985). With regard to adult neurogenesis, it has been found that the precursor cells of the granule cells exist near the border between the hilus and the dentate granular layer containing the subgranular zone (Guéneau et al., 1979, 1982; Kaplan and Bell, 1984; Altman and Bayer, 1990), and that the newly generated cells are then added into the deepest portion of the dentate granular layer (Crespo et al., 1986), where they differentiate into dentate granule cells, extending dendrites and axons (mossy fibers) (Stanfield and Trice, 1988) and receiving synaptic inputs (Kaplan and Hinds, 1977; Kaplan and Bell, 1984). However, though many have reported on the above aspects of neu-

\footnotetext{
Received Aug. 31, 1992; revised Nov. 27, 1992; accepted Dec. 7, 1992.

We thank Dr. Katsuhiko Ono for providing mAb AF-11. This work was supported by a Grant-in-Aid for Scientific Research from The Japanese Ministry of Education, Science and Culture (02640585 and 04770039).

Correspondence should be addressed to Dr. Tatsunori Seki, Department of Anatomy, Juntendo University, School of Medicine, Hongo 2-1-1, Bunkyo-ku, Tokyo 113, Japan.

Copyright (C) 1993 Society for Neuroscience $0270-6474 / 93 / 132351-08 \$ 05.00 / 0$
}

rogenesis, no study has yet appeared with regard to specific molecules that may be involved in the development of the newly generated granule cells.

The neural cell adhesion molecule (NCAM), particularly its highly polysialylated form, is considered to be among the possible molecular candidates that are specifically expressed in immature neuronal elements (Rutishauser and Jessell, 1988; Linnemann and Bock, 1989). NCAM is a wcll-known glycoprotein that is involved in cell-to-cell adhesion, and its glycosylated form differs in the developing and the adult nervous tissues (Edelman, 1986; Rutishauser et al., 1988). In the developing tissues, NCAM is highly sialylated with $\alpha 2-8$ polysialic acid (PSA) (NCAM-H), whereas in the adult tissues, NCAM has a low content of polysialic acid (NCAM-L) (Hoffman et al., 1982; Finne et al., 1983; Hoffman and Edelman, 1983; Regan, 1991).

In a previous study, using a monoclonal antibody against a long PSA chain of NCAM-H, we have shown that a persistent NCAM-H expression occurs in the cells in the deepest portion of the dentate granule cell layer of the adult rat (Seki and Arai, 1991b). Therefore, pursuing our research further, this study was undertaken to determine whether NCAM-H expression is found in newly formed granule cells in the adult rat, by labeling these cells with 5-bromo-2'-deoxyuridine (BrdU), a thymidine analog, followed by a double immunostaining for NCAM-H and BrdU. Further, immunoelectron microscopic observations were also performed to determine what cell types express NCAM-H. Additionally, to exclude the possibility that glial cells in the granule layer may also express NCAM-H, double immunostaining for NCAM-H and glial fibrillary acidic protein (GFAP) was undertaken.

\section{Materials and Methods}

Antibodies. Mouse IgG monoclonal anti-BrdU was obtained from Becton Dikinson (San Jose, CA); mouse IgG monoclonal anti-GFAP, from Boehringer Mannheim; and alkaline phosphatase-conjugated goat antimouse IgG and peroxidase-conjugated goat anti-mouse IgM, from Cappel (West Chester, PA). The mouse monoclonal antibody (mAb) 12E3 (IgM) had been raised in our laboratory and was found to recognize the PSA portion of NCAM-H (Seki and Arai, 1991a). The mouse mAb AF1 1 (IgGl) was a kind gift of Dr. K. Ono (Okayama University, Japan) (Ono et al., 1992).

BrdU labeling procedure. Two sets of rats were used for BrdU labelings. Nineteen male Wistar rats at postnatal day 35 (P35) were given an intravenous injection of $\mathrm{BrdU}$ (Sigma) dissolved in $0.007 \mathrm{~N} \mathrm{NaOH}$ in $0.9 \% \mathrm{NaCl}(100 \mu \mathrm{g} / \mathrm{gm}$ body weight $)$. In male Wistar rats at P56, the BrdU injections were performed intraperitoneally with BrdU at $2 \mathrm{hr}$ intervals over an $8 \mathrm{hr}$ period.

Tissue preparation. To detect the NCAM (peptide portion), NCAM-H (PSA portion), and GFAP immunoreactivities, male Wistar rats at P56 were used, and vibratome or cryostat sections were prepared as has been described previously (Seki and Arai, 1991b). 
To detect the BrdU and NCAM-H immunoreactivities, paraffin sections were used. Two hours, $12 \mathrm{~d}$, and $80 \mathrm{~d}$ after the BrdU injection, animals were perfused with $70 \%$ ethanol under deep sodium pentobarbital anesthesia, and after decapitation their brains were postfixed overnight in the same solution at $4^{\circ} \mathrm{C}$. Dissected brains were embedded in paraplast (Sherwood Medical Industries, St. Louis, MO), sectioned at $7 \mu$ coronally, and mounted on glass slides. Sections from the approximate midpoint of the septotemporal axis of the hippocampal formation were selected for the subsequent immunohistochemical staining. These sections were deparaffinized in xylene, hydrated, and treated with $0.3 \%$ $\mathrm{H}_{2} \mathrm{O}_{2}$ in absolute methanol for $30 \mathrm{~min}$. The sections were then rinsed in phosphate-buffered saline (PBS) and immersed in $0.07 \mathrm{~N} \mathrm{NaOH}$ for 2 min to produce a single-stranded DNA and then in $0.1 \mathrm{M} \mathrm{PBS}$ at $\mathrm{pH}$ 8.5 for $30 \mathrm{sec}$ (Miller and Nowakowski, 1988).

Immunostaining method. The single immunostainings for the PSA portion of NCAM-H and the peptide portion of NCAM were carried out using $\mathrm{mAb} 12 \mathrm{E} 3$ and anti-mouse IgM conjugated with peroxidase, and $\mathrm{mAb}$ AF1 1 and anti-mouse IgG conjugated with peroxidase, respectively, as has been described previously (Seki and Arai, 1991a).

Double immunostaining procedure using the second antibodies conjugated with alkaline phosphate or peroxidase (Mason and Sammons, 1978) was used to detect simultaneously the BrdU and NCAM-H antigens or the GFAP and NCAM-H antigens in the same section. After washing in PBS ( $\mathrm{pH} 7.4$ ), the sections were incubated overnight at $4^{\circ} \mathrm{C}$ in a mixture of mouse IgM mAb 12E3 (1:5000) and mouse IgG antiBrdU (1:150) or mouse IgG anti-GFAP (1:100) in PBS containing 1\% bovine serum albumin (BSA) and $1 \%$ normal goat serum.

The sections were washed in PBS and then incubated for $2-3 \mathrm{hr}$ at room temperature with a mixture of anti-mouse IgM conjugated with peroxidase (1:100) and anti-mouse IgG conjugated with alkaline phosphatase $(1: 150)$ in Tris-buffered saline (TBS) at a pH of 7.4 containing BSA. Following the TBS washing, the sections were incubated with $0.02 \% 3,3$ '-diaminobenzidine tetrahydrochloride (DAB) and $0.005 \%$ $\mathrm{H}_{2} \mathrm{O}_{2}$ in $0.05 \mathrm{M}$ Tris buffer ( $\mathrm{pH} \mathrm{7.6)}$ for 5-10 min, rinsed in TBS, and then reacted with $0.1 \%$ fast blue $\mathrm{BB}$ in an $0.005 \mathrm{M}$ 2-amino-2-methyl1,3-propanediol buffer (pH 9.75) containing $0.2 \mathrm{mg} / \mathrm{ml}$ naphthol AS BI. The slides were rinsed in distilled water, and mounted in Aquatex (Merck).

The reaction products of alkaline phosphatase and peroxidase yielded a blue and a brown color, respectively. A preliminary experiment had shown that no cross-reaction between the two antisera was taking place, and that no immunoreactivity was found when the primary antibodics were omitted, or when mAb $12 \mathrm{E} 3$ was preincubated with colominic acid, composed of $\alpha 2-8$ polysialic acid.

Quantitative analysis. Medium-sized nuclei that reacted with the antiBrdU antibody in the granule layer and the subgranule zone of the dentate gyrus were selected, and the very small-sized nuclei were discarded. The BrdU-positive cells were classified into four groups on the basis of their position, and on the presence of NCAM-H immunoreactivity. The locations of the BrdU-positive cells were subgrouped into a subgranular zone, the first row (the deepest portion of the granular layer), and the second or even higher row from the bottom of the granular layer. When BrdU-positive cells appeared to be positioned between the first and the second rows, these cells were considered as being cells of the first row; such cells were only considered to be part of the second row when the cell's position almost overlaid a cell of the first row. Similarly, cells positioned between the first row and the subgranular zone were grouped as belonging to the first row. The BrdU-labeled cells were counted in every third section, and an average of 30 sections that contain right and left hippocampal formations per rat were analyzed.
Each group consisted of six or seven rats. The statistical significance of the results was assessed by using a Student's $t$ test.

Electron microscopic procedures. Male Wistar rats 47 or $56 \mathrm{~d}$ old were perfused with a mixture of $4 \%$ paraformaldehyde and $0.1 \%$ glutaraldehyde in phosphate buffer $(\mathrm{PB})$ at $4^{\circ} \mathrm{C}$ under deep sodium pentobarbital anesthesia. The brains were then removed and immersed overnight in $4 \%$ paraformaldehyde in $\mathrm{PB}$ at $4^{\circ} \mathrm{C}$. After washing with PBS, vibratome sections were cut at $50 \mu \mathrm{m}$ and rinsed with PBS. Preembedding immunostaining was performed according to a method described by Martini and Schachner (1986) with minor modifications. In brief, these vibratome sections were incubated in $0.1 \mathrm{M} \mathrm{NaIO}_{4}(10 \mathrm{~min})$ and then in $\mathrm{NaBH}_{4}(15 \mathrm{~min})$, followed by immersion in $5 \%$ dimethyl sulfoxide $(30 \mathrm{~min})$ at room temperature. Next, the sections were incubated with mouse IgM mAb 12E3 (1:5000) overnight at $4^{\circ} \mathrm{C}$, and then with antimouse IgM conjugated with peroxidase $(1: 100)$ for $3 \mathrm{hr}$ at room temperature, and fixed with $1 \%$ glutaraldehyde for $1 \mathrm{~min}$ at $4^{\circ} \mathrm{C}$. Following this, the sections were incubated with $\mathrm{DAB}$ solution for $30 \mathrm{~min}$ and then with a DAB solution containing $0.005 \% \mathrm{H}_{2} \mathrm{O}_{2}$ for $5-10 \mathrm{~min}$. Each of the above steps was followed by washing with PBS. Finally, the sections were postfixed with $2 \% \mathrm{OsO}_{4}$ in $\mathrm{PB}$, dehydrated, and embedded in Epok 812 (Oken-Shoji Co., Ltd., Tokyo).

\section{Results}

Strong NCAM-H immunoreactivity was found in the cells with apical processes in the deepest portion of the dentate granule layer, and axons (mossy fibers) that ran through the stratum lucidum of the CA3 region of the hippocampal pyramidal cells (Fig. 1). On the other hand, immunoreactivity for peptide portion of NCAM was seen throughout the hippocampal formation, but was stronger in the stratum lucidum of the $\mathrm{CA} 3$ region and the inner third of the molecular layer of the dentate gyrus (Fig. 2).

\section{GFAP and NCAM-H double staining results}

GFAP immunoreactivity (blue color) was found in star-shaped astrocytes that were located throughout the hippocampal formation, and the palisades of glial processes in the dentate granular layer (Fig. 3), in agreement with results observed by Kálmán and Hajós (1989). The radially oriented processes of the GFAPpositive glial cells transversed the granular and the molecular layer, and their cell bodies were located near the border between the granular layer and the hilus. Double immunostaining revealed that the GFAP and the NCAM-H (brown color) immunoreactivities were present in separate processes (Fig. 3), thereby suggesting that GFAP-positive glial cells do not express NCAM-H.

\section{Electron microscopic findings}

To determine what types of cells express NCAM-H in the granular layer and the subgranular zone, preembedding immunoelectron microscopy was carried out. In the decpest portion of the granular layer, NCAM-H immunoreactivity was detected

Figure 1. Immunoreactivity for NCAM-H in a vibratome section of the hippocampus formation of P56 rat, cut perpendicularly to the septotemporal axis. $C A 1$ and $C A 3$, fields $C A 1$ and $C A 3$ of Ammon's horn; $G L$, granular layer; $H$, hilus; $M F$, mossy fiber; $M L$, molecular layer. Scale bar, 500 $\mu \mathrm{m}$.

Figure 2.Immunoreactivity for peptide portion of NCAM in a vibratome section of the hippocampus formation of P56 rat, cut perpendicularly to the septotemporal axis. Abbreviations are as in Figure 1. Scale bar, $500 \mu \mathrm{m}$.

Figure 3. Double immunostaining of the granular layer of the dentate gyrus for GFAP (blue) and NCAM-H (brown). Note that the GFAP- and the NCAM-H-positive processes are separately seen. Cryostat section. Abbreviations are as in Figure 1 . Scale bar, $20 \mu \mathrm{m}$.

Figure 4. Double immunostaining of the granular layer of the dentate gyrus for BrdU (bhue) and NCAM (brown). Rats were injected with BrdU at P35 and were killed at $2 \mathrm{hr}(a)$, at $12 \mathrm{~d}(b)$, and at $80 \mathrm{~d}(c)$ after the injection. $a$, BrdU-positive nuclei are situated side by side in the subgranular layer. NCAM-H-positive cells are located in the first row of the granular layer. $b$, A BrdU-positive nucleus is situated within an NCAM-H-positive cell. $c$, A BrdU-positive nucleus is positioned in the second row, while an NCAM-H-positive cell is seen in the first row. Intcrfercnce contrast optics. Abbreviations are as in Figure 1. Scale bars, $10 \mu \mathrm{m}$. 

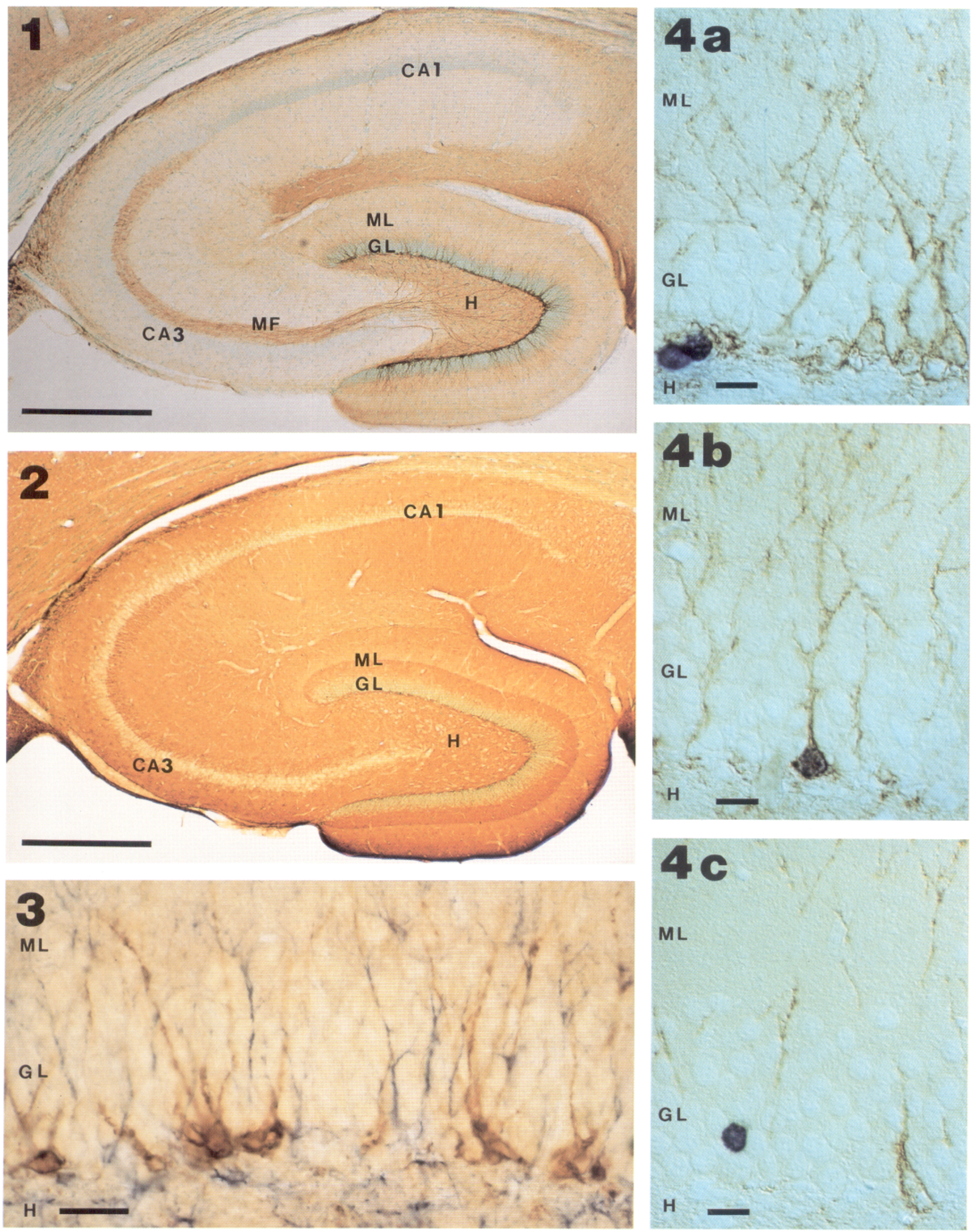

ML
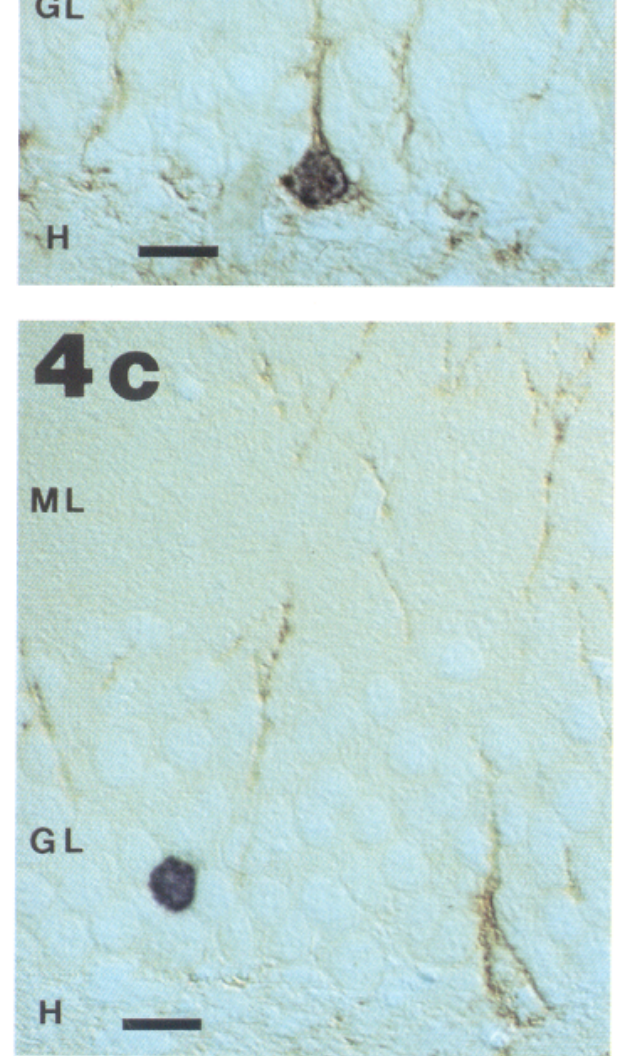

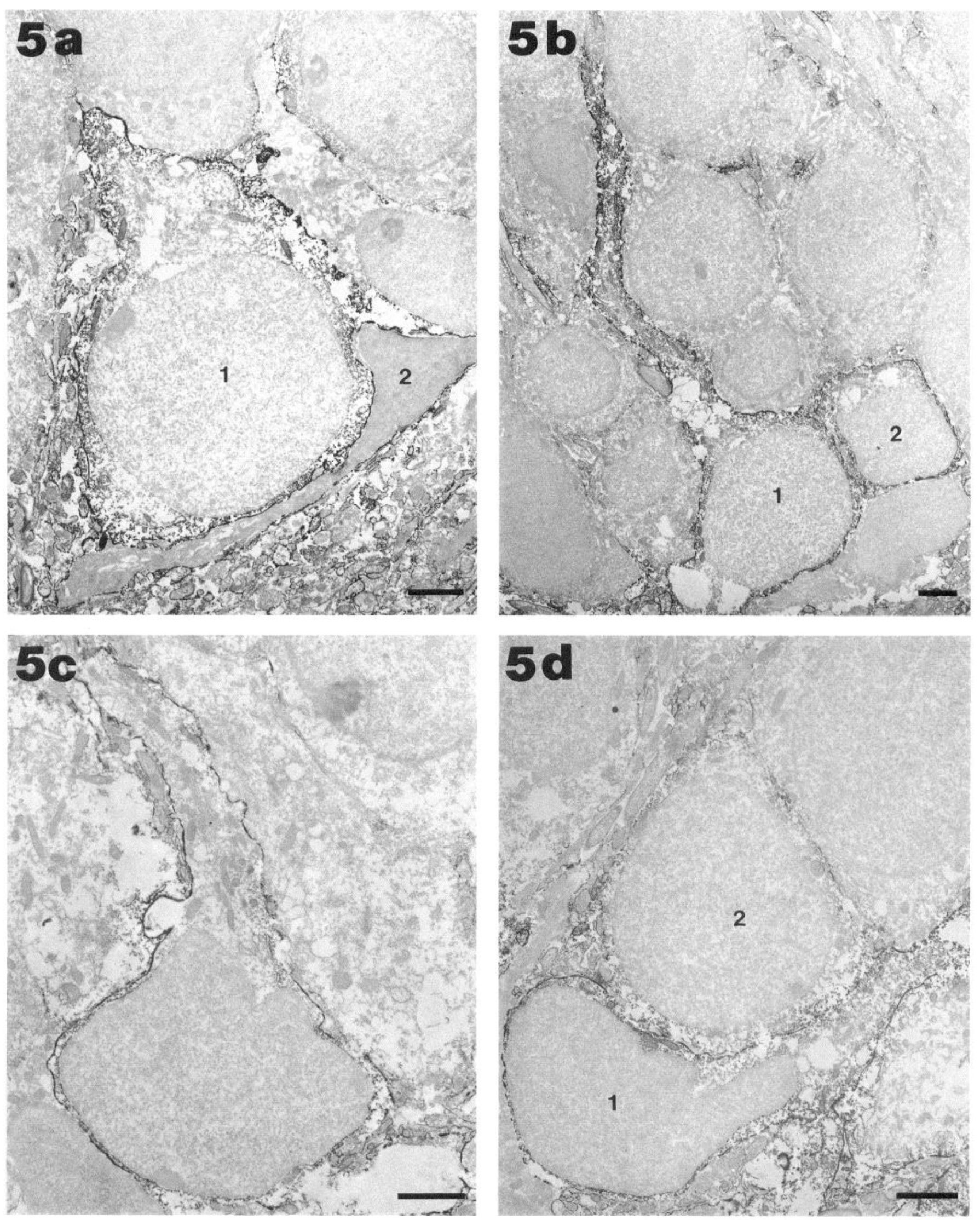

Figure 5. Immunoelectron microscopic photographs of NCAM-H-positive cells in the deepest portion of the granule cell layer. $a$, A cell showing typical granule cell features $(I)$ and a cell with a dark triangular nucleus and cytoplasm (2). $b$, A presumptive immature cell with a rounded nucleus that is similar to a granule cell (1) and a presumptive immature cell with polygonal nucleus (2) side by side. $c$, A presumptive immature cell with a polygonal and irregular nucleus. $d$, A presumptive immature cell with a flat and irregular nucleus $(l)$ and a granule cell showing weak NCAM-H immunoreactivity (2). Note the narrower rim of cytoplasm around the nuclei $(b, c$, and $d, 1)$. Scale bars, $2 \mu \mathrm{m}$. 


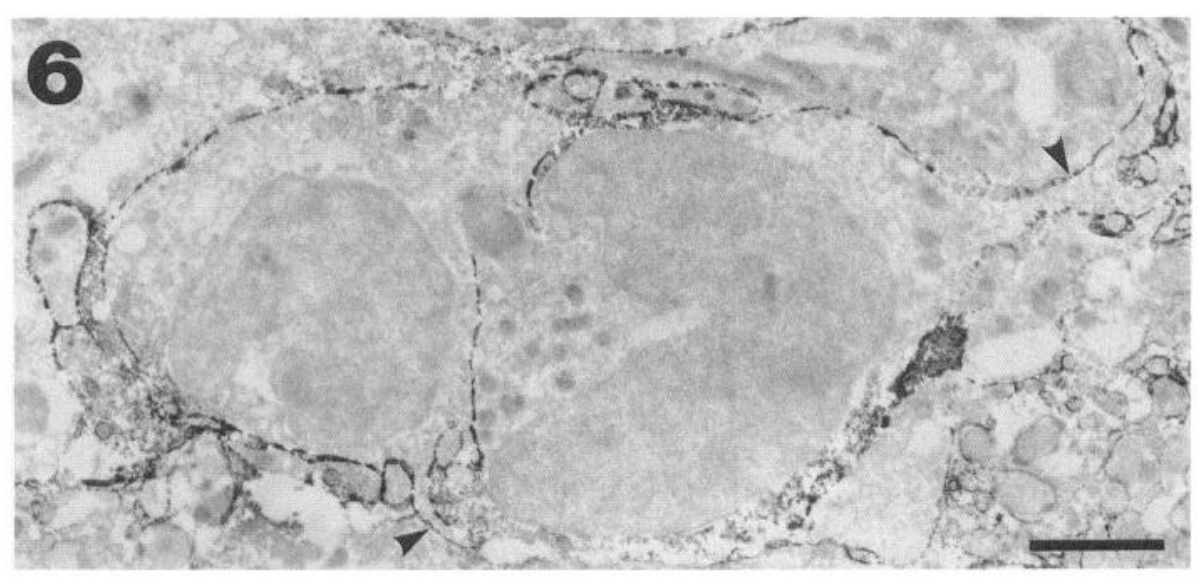

Figure 6. Immunoelectron microscopic photograph of NCAM-H-positive cells in subgranular zone: two closely united cells with irregular nuclei that appear to be cells just after cell division. Scale bar, $2 \mu \mathrm{m}$. in several types of cells, where strong immunoreactivity was associated with the cell membrane, and moderate immunoreactivity was occasionally detectable in the cytoplasm of the cell body and apical process, just beneath the cell membrane (Figs. $5 a-d, 6$ ). In the mossy fibers, however, the cytoplasmic label for NCAM-H has scarcely been detected (Seki and Arai, 1991b). Thus, it is unlikely that the immunoreaction is an artifact. Since sialyltransferase has been demonstrated in Golgi membrane fraction (Regan, 1991), the cytoplasmic immunoreactivity may be associated with the synthesis of NCAM-H. At times, the two or more NCAM-H-positive cells were found positioned side by side (Figs. $5 b, 6$ ).

About half of the NCAM-H-immunoreactive cells had the features of dentate granular cells, such as a rounded or oval nuclei, uniformly dispersed chromatin, peripherally located nucleoli, and narrow rim of cytoplasm (Laatsch and Cowan, 1966) (Fig. $5 a$ ). The rest of the immunoreactive cells had triangular, polygonal, or irregular nuclei with uniformly dispersed chromatin, and cytoplasms with even narrower rims than the cytoplasms of typical granule cells (Fig. $5 b-d$ ). Occasionally, their nuclei were irregularly creased on the side of the main process (Fig. 5c,d). A small number of NCAM-H-positive cells had electron-dense nuclei and cytoplasms (Fig. $5 a$ ).

In the subgranular layer, the NCAM-H immunoreactivity was occasionally detected in cells that had closely united with another cell; these cells showing irregular nuclei and small protrusions (Fig. 6), indicating that these cells may have just undergone cell division.

As far as we could be detected, NCAM-H immunoreactivity was not present in cells manifesting typical pyramidal basket cell features, such as infolded nuclei, intranuclear rods and sheets, and a greater abundance of perikaryal organelles (Ribak and Anderson, 1980). Further, NCAM-H immunoreactivity also was not detected in cells that manifested the characteristic features of glial cells, such as distinctive glial filaments and glycogen granules (Peters et al., 1991).

\section{BrdU analysis results}

Since the number of the BrdU-labeled nuclei was far smaller in the BrdU-injected 56-d-old rats than in the 35-d-old BrdUinjected rats, for the quantitative analysis the 35 -d-old rats were used. In the rats from $2 \mathrm{hr}$ to $80 \mathrm{~d}$ after the injection, averages of 4.8-5.4 BrdU-labeled nuclei per section were found in the subgranular zone and the granular layer of the dentate gyrus. A few BrdU-labeled cells were seen scattered throughout the other hippocampal areas in rats that were killed from $2 \mathrm{hr}$ to $80 \mathrm{~d}$ after the BrdU injection. As for the reaction products of the alkaline phosphatase, they were homogeneous and completely filled the nuclei, although the reaction was found to be punctuate in some nuclei of rats killed $80 \mathrm{~d}$ after the injection.

The number of NCAM-H-positive cell bodies, dendrites, and axons appeared to decrease with aging, but a substantial amount of NCAM-H-positive neural components was still found in the P115 rat.

In rats that were killed $2 \mathrm{hr}$ after the BrdU injections, cells with a BrdU-labeled nucleus were found in the subgranular zone and in the deepest portion of the granular layer of the dentate gyrus (Figs. $4 a, 7$ ), and occasionally, two or more BrdU-labeled nuclei were seen side by side. The BrdU-labeled nuclei were oval, rounded, or triangular, and either the same size or smaller than the nuclei of the granule cells.

At $12 \mathrm{~d}$ after the BrdU injection, the number of BrdU-positive nuclei in the subgranular layer had decreased $(P<0.001)$, and $82 \%$ of BrdU-labeled nuclei were found within the NCAMpositive cell bodies in the deepest portion of the dentate granular layer, although $12 \%$ of BrdU-positive cells that were negative for NCAM-H were present in the first row of the granular layer and in the subgranular zone (Figs. $4 b, 7$ ). The NCAM-H-positive cells with BrdU-labeled nuclei were mainly oval or triangular, and of the total number of double-positive cells, $60 \%$ of these cells appeared to possess apical processes that resembled the apical dendrites of granule cells.

At $80 \mathrm{~d}$ after the BrdU injection, the cells that were positive for both BrdU and NCAM-H disappeared, and BrdU-labeled nuclei were mainly detected in the first and the second row from the bottom (inner side) of the granular layer (Figs. 4c, 7). A very small number of BrdU-labeled nuclei were located in higher rows above the third row of the granule cell layer. The number of BrdU-labeled cells was significantly greater in the second and higher row at $80 \mathrm{~d}$ than at $12 \mathrm{~d}$ after the BrdU injection $(P<$ 0.001 ).

In the BrdU-injected P56 rats that were killed $12 \mathrm{~d}$ later, a few cells positive for both NCAM-H and BrdU were detected in the deepest portion of the dentate granule layer and the shape of some NCAM-H- and BrdU-positive cells resembled granule cells.

\section{Discussion}

Our previous studies have shown that NCAM-H is expressed only by the cells in the deepest portion of the granular layer of 


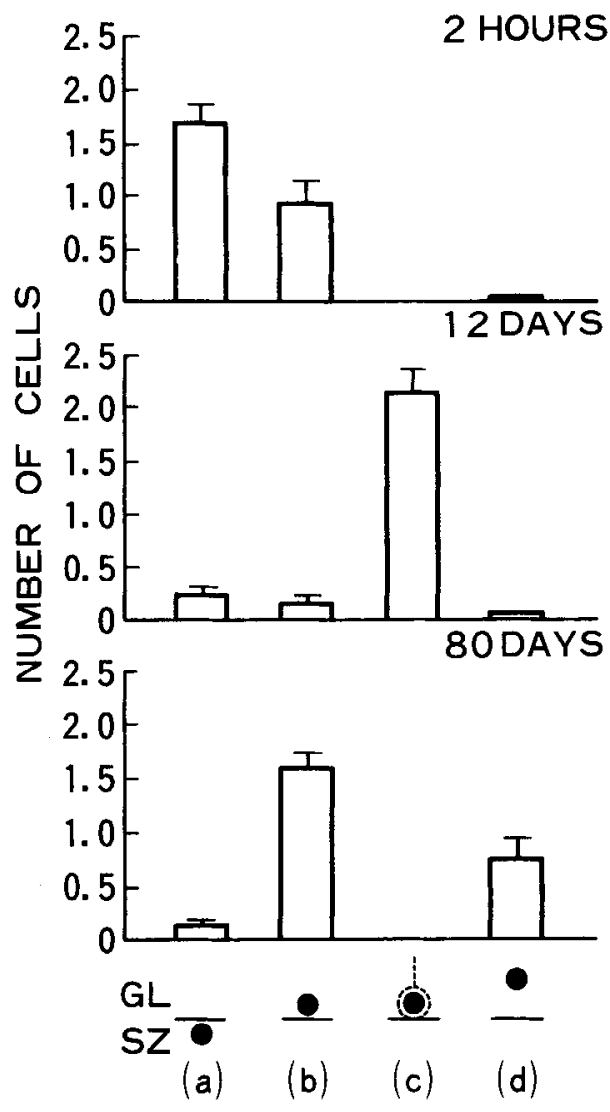

Figure 7. Distribution of number of BrdU-labeled cells with or without NCAM-H immunoreactivity at different positions in the granular layer and subgranular zone in a section of the hippocampal formation from the rat at $2 \mathrm{hr}$, at $12 \mathrm{~d}$, and at $80 \mathrm{~d}$ after the BrdU injection. $a$, BrdUlabeled cells in the subgranular zone $(S Z) ; b, \mathrm{BrdU}$-labeled cells in the first row of the granular layer $(G L) ; c$, BrdU-labeled cells positive for NCAM-H in the first row of the granular layer; and $d$, BrdU-labeled cells in the second row of granular layer. Error bars represent $\mathrm{SE}$.

the adult dentate gyrus, in which newly generated granule cells are thought to be situated (Seki and Arai, 1991b). In line with our ongoing research, the results of this present study now provide the first direct evidence of a correlation between the NCAM$\mathrm{H}-$-expressing cells and the continued neurogenesis of granule cells in the adult dentate gyrus, and support our conjecture that NCAM-H is transiently expressed by the newly generated granule cells in the adult dentate gyrus.

\section{Nature of NCAM-H-expressing cells}

Present immunoelectron microscopic study has demonstrated that at least half of the NCAM-H-expressing cells have the ultrastructural characteristics of granule cells, which is in accord with the results of previous light microscopic observations showing that the majority of NCAM-H-positive cells in the adult dentate gyrus resemble dentate granule cells (Seki and Arai, 1991 b). Recently, Le Gal La Salle et al. (1992) have also described at light microscopic level that NCAM-H immunoreactivity is detectable in pyramidal-shaped cells of the dentate granular layer in the adult rat.

Although we could not determine exact cell types of the rest of the NCAM-H-expressing cells, we were able to find that these cells do not have the typical ultrastructural characteristics of glia cells or basket cells. Further, our double immunostaining results indicate that NCAM-H-expressing cells have no connection with GFAP-positive radial glial cells, and probably with immature radial glial cells, since GFAP expression has been rcportcd to appear at a very early stage of glial cell differentiation (Levitt et al., 1981).

Our immunoelectron microscopic examination also revealed that NCAM-H-expressing cells were occasionally positioned side by side. Since this same side-by-side positioning was observed in BrdU-labeled cells, particularly just after the BrdU injection, these NCAM-H-positive cells may be cells that appeared relatively soon after cell division. In addition, some of them had narrower rims of basal cytoplasm than do typical granule cells, and such narrower rims can be regarded as characteristic of the developing neuron in the basal part of the dentate granular layer (Guéneau et al., 1982). It is therefore possible that the majority of the NCAM-H-expressing cells except for typical granule cells may be immature dentate granule cells. However, the possibility still remains that a very small number of glial cells (microglia and oligodendroglia) and immature basket cells in the dentate granular layer may cxpress NCAM-H.

\section{Newly generated cells express NCAM-H}

We have demonstrated that $12 \mathrm{~d}$ after the BrdU injection, labeled nuclei were detected within the NCAM-H-expressing cells in the deepest portion of the granule cell layer and the majority of the double-labeled cells were similar in shape to granule cells at light microscopic level. Based on these results, together with the findings of immunoelectron microscopy and double staining for GFAP and NCAM-H, it is probable that the BrdU-labeled cells, or the newly generated cells express NCAM-H and that they are mainly composed of granule cells and presumptive immature granule cells.

The disappearance of the NCAM-H expression in the BrdUlabeled cells of the rats killed $80 \mathrm{~d}$ after the BrdU injection suggests that newly generated granule cells transicntly cxprcss NCAM-H and no longer do so as they mature. In addition, some BrdU-labeled nuclei without an NCAM-H-expressing cell body were found in the second row of the granule cell layer 80 $\mathrm{d}$ after the injection. One possible explanation for these results may be that as newly generated cells are added beneath the BrdU- and NCAM-H-positive cells of the first row, the BrdUlabeled cells situated in the second row in the same manner as has been described by Crespo et al. (1986) and cease their NCAM-H expression. However, more than half of BrdU-labeled cells remained in the first row. This fact may indicate that further newly generated cells are not added there, probably because the number of postnatally generated cells gradually decreases with increasing age (Altman and Das, 1965). This interpretation is in good accord with our result that BrdU-labeled cells decreased as the age of the rat increased from P35 to P56.

Although relatively young adult rats were used in this study, it is probable that the adult-type cell proliferation already occurs in the P35 and P56 rats, since Altman and Bayer (1990) have shown that the subgranular zone of the rat becomes the source of granule cells produced during the juvenile and adult period by the first postnatal month. However, it is important to determine how long postnatal neurogenesis and NCAM-H exprcssion continuc in the dentate granule cells, so as to determine the physiological role of the NCAM-H expression in newly generated granule cells. Thus, further experiments using older rats are needed. 
Role of the NCAM-H expression in newly generated granule cells

It is gencrally accepted that NCAM-H expression is mainly confined to the developmental period (Hoffman et al., 1982; Sunshine et al., 1987). Several in vivo and in vitro experiments have shown that NCAM-H is involved in various developmental events of the nervous system such as the migration of neurons (Heckmat et al., 1990; Murakami et al., 1991), the extension of neurites (Doherty et al., 1990), nerve branching (Landmesser et al., 1990), and specific pathfinding (Tang et al., 1992). Similarly, our finding that newly generated granule cells transiently express NCAM-H strongly suggests that like the developing neural tissues, the NCAM-H expression in the adult hippocampal formation is associated with the growth process of the newly generated granule cells. Further, a possible NCAM-H involvement in the adult neurogenesis has been reported in the adult mouse olfactory system, where the localization of the NCAM-H expression was found to be closely associated with the occurrence of neurogenesis in the olfactory epithelium and in the subventricular layer of the adult olfactory bulb (Miragall et al., 1988, 1990).

However, the NCAM-H expression during the adult stage has been found even in regions without adult neurogenesis, such as the piriform cortex (Seki and Arai, 1991a), the hypothalamoneurohypophysial system (Theodosis et al., 1991), and optic nerve (Bartsch et al., 1990). Additionally, it has been reported that in kainic acid-induced epileptic rats, the reexpression of NCAM-H appeared in the astrocyte of the hippocampal formation, particularly of the hilus (Le Gal La Salle et al., 1992). The NCAM-H expression in thece neural substrates is thought to indicate an NCAM-H involvement in neural plasticity, including the reorganization of synaptic contacts and the sprouting of dendrites and axons. Thus, NCAM-H-expressing granule cells may be involved in neural plasticity at a later stage when NCAM-H expression still continues in the granule cell.

The restricted distribution of NCAM-H expression in the hippocampal formation suggests that the polysialylation of NCAM, rather than the expression of the peptide portion of NCAM, plays an important role in adult neurogenesis of granule cells, since the expression of the peptide portion of NCAM was found to be distributed throughout the hippocampal formation in agreement with the data of Goldowitz et al. (1990). In comparison to the other cell adhesion molecules, a unique NCAM-H feature is that the polysialic acid portion of the NCAM-H has been found to reduce cell adhesiveness (Hoffman and Edelmann, 1983; Rutishauser et al., 1988). Recently, it has been proposed that the PSA of NCAM-H alone can regulate the function of the other cell surface ligands (i.e., L1, laminin), probably because the negatively charged large volume of PSA interferes with cellto-cell contact by steric hindrance (Acheson et al., 1991), and that the PSA affects the intercellular space in apposing cells, and provides a physical coating around a cell (Yang et al., 1992). According to this view, it is possible that the PSA portion of NCAM-H is needed by the newly generated granule cells to develop their neurites and to form new neural circuits in the densely packed neural elements of the adult hippocampal formation and to keep themselves from forming inappropriate cell adherences.

So far, the precise role that newly generated dentate granule cells play in the physiological function of the hippocampal formation is not yet clear, although it is supposed that the newly generated cells make synaptic contacts with the surrounding neuronal elements, probably by being influenced by sensory inputs, and that they modify the neuronal circuits of the adult hippocampal formation. In this regard, it is noteworthy that NCAM-H immunostaining may provide a way to detect the dendrites arising from newly generated dentate granule cells, which receive highly regular organized inputs, such as the perforant path, and associational and commissural afferents. Therefore, this procedure may prove to be a powerful tool for investigating the physiological role of the newly generated granule cells in adult hippocampal formation, including neural plasticity, memory, and learning.

\section{References}

Acheson A, Sunshine JL, Rutishauser U (1991) NCAM polysialic acid can regulate both cell-cell and cell-substrate interactions. J Cell Biol 114:143-153.

Altman J, Bayer SA (1990) Migration and distribution of two populations of hippocampal granule cell precursors during the perinatal and postnatal periods. J Comp Neurol 301:365-381.

Altman J, Das GD (1965) Autoradiographic and histological evidence of postnatal hippocampal neurogenesis in rats. J Comp Neurol 124: 319-336.

Bartsch U, KirchhoffF, Schachner M (1990) Highly sialylated N-CAM is expressed in adult mouse optic nerve and retina. J Neurocytol 19: $550-565$.

Bayer SA, Yackel JW, Puri PS (1982) Neurons in the rat dentate gyrus granular layer substantially increase during juvenile and adult life. Science 216:890-892.

Boss B, Peterson GM, Cowan WM (1985) On the number of neurons in the dentate gyrus of the rat. Brain Res 338:144-150.

Crespo D, Stanfield BB, Cowan WM (1986) Evidence that late-generated granule cells do not simply replace earlier formed neurons in the rat dentate gyrus. Exp Brain Res 62:541-548.

Doherty P, Cohen J, Walsh FS (1990) Neurite outgrowth in response to transfected N-CAM changes during development and is modulated by polysialic acid. Neuron 5:209-219.

Edelman GM (1986) Cell adhesion molecules in neural histogenesis. Annu Rev Physiol 48:417-430.

Finne J, Finne U, Deagostini-Razin H, Goridis C. (1983) Occurrence of $\alpha 2-8$ linked polysialosyl units in a neural cell adhesion molecule. Biochem Biophys Res Commun 112:482-487.

Goldowitz D, Barthels D, Lorenzon N, Jungblut A, Wille W (1990) NCAM gene expression during the development of cerebellum and dentate gyrus in the mouse. Dev Brain Res 52:151-160.

Guéneau G, Drouet J, Privat A, Court L (1979) Differential radiosensitivity of neurons and neuroglia of the hippocampus in the adult rabbit. Acta Neuropathol (Berl) 48:199-209.

Guéneau G, Privat A, Drouet J, Court L (1982) Subgranular zone of the dentate gyrus of young rabbits as a secondary matrix. A highresolution autoradiographic study. Dev Neurosci 5:345-358.

Heckmat A, Bitter-Suermann D, Schachner M (1990) Immunocytological localization of the highly polysialylated form of the neural cell adhesion molecule during development of the murine cerebellar cortex. J Comp Neurol 291:457-467.

Hoffman S, Edelman GM (1983) Kinetics of homophilic binding by embryonic and adult forms of the neural cell adhesion molecule. Proc Natl Acad Sci USA 80:5762-5766.

Hoffman S, Sorkin BC, White PC, Brackenbury R, Mailhammer R, Rutishauser U, Cunningham BA, Edelmann GM (1982) Chemical characterization of a neural cell adhesion molecule purified from embryonic brain membranes. J Biol Chem 257:7720-7729.

Kálmán M, Hajós F (1989) Distribution of glial fibrillary acidic protein (GFAP)-immunoreactive astrocytes in the rat brain. I. Forebrain. Exp Brain Res 78:147-163.

Kaplan MS, Bell DH (1984) Mitotic neuroblasts in the 9-day-old and 11-month-old rodent hippocampus. J Neurosci 4:1429-1441.

Kaplan MS, Hinds JW (1977) Neurogenesis in the adult rat: electron microscopic analysis of light radioautographs. Science 197:1092-1094.

Laatsch PH, Cowan WM (1966) Electron microscopic studies of the dentate gyrus of the rat. I. Normal structure with special reference to synaptic organization. J Comp Neurol 128:359-396. 
Landmesser L, Dahm L, Tang J, Rutishauser U (1990) Polysialic acid as a regulator of intramuscular nerve branching during embryonic development. Neuron 4:655-667.

Le Gal La Salle G, Rougon G, Valin A (1992) The embryonic form of neural cell surface molecule (E-NCAM) in the rat hippocampus and its reexpression on glial cells following kainic acid-induced status epilepticus. J Neurosci 12:872-882.

Levitt PM, Cooper ML, Rakic P (1981) Coexistence of neuronal and glial precursor cells in the cerebral ventricular zone of the fetal monkey: an ultrastructural immunoperoxidase analysis. J Neurosci 1:2739.

Linnemann D, Bock E (1989) Cell adhesion molecule in neural development. Dev Neurosci 11:149-173.

Martini R, Schachner M (1986) Immunoelectron microscopic localization of neural cell adhesion molecules (L1, N-CAM, MAG) and their shared carbohydrate epitope and myelin basic protein in developing sciatic nerve. J Cell Biol 103:2439-2448.

Mason DY, Sammons R (1978) Alkaline phosphatase and peroxidase for double immunoenzymatic labelling of cellular constituents. J Clin Pathol 31:454-460.

Miller MW, Nowakowski RS (1988) Use of bromodeoxyuridine-immunohistochemistry to examine the proliferation, migration and time of origin of cells in the central nervous system. Brain Res 457:44-52.

Miragall F, Kadmon G, Husmann M, Schachner M (1988) Expression of cell adhesion molecules in the olfactory system of the adult mouse: presence of the embryonic form of N-CAM. Dev Biol 129:516-531.

Miragall F, Kadmon G, Faissner A, Antonicek H, Schachner M (1990) Retention of $\mathrm{J} 1 /$ tenascin and the polysialylated form of the neural cell adhesion molecule (N-CAM) in the adult olfactory bulb. J Neurocytol 19:899-914.

Murakami S, Seki T, Wakabayashi K, Arai Y (1991) The ontogeny of luteinizing hormone-releasing hormone (LHRH) producing neurons in the chick embryo: possible evidence for migrating LHRH neurons from the olfactory epithelium expressing a highly polysialylated neural cell adhesion molecule. Neurosci Res 12:421-431.
Ono K, Asou H, Yamada M, Tokunaga A (1992) Gradient expression of neural cell adhesion molecule (NCAM) in the pontine migratory stream of fetal rats. Neurosci Res 15:221-223.

Peters A, Palay SL, Webster HF (1991) The fine structure of the nervous system. Neurons and their supporting cells, $3 \mathrm{~d}$ ed. New York: Oxford UP.

Regan CM (1991) Regulation of neural cell adhesion molecule sialylation state. Int J Biochem 23:513-523.

Ribak CE, Anderson L (1980) Ultrastructure of the pyramidal basket cells in the dentate gyrus of the rat. J Comp Neurol 192:903-916.

Rutishauser U, Jessell TM (1988) Cell adhesion molecules in vertebrate neural development. Physiol Rev 68:819-857.

Rutishauser U, Acheson A, Alison KH, Mann DM, Sunshine J (1988) The neural cell adhesion molecule (NCAM) as a regulator of cell-cell interactions. Science 240:53-57.

Seki T, Arai Y (1991a) Expression of highly polysialylated NCAM in the neocortex and piriform cortex of the developing and the adult rat. Anat Embryol (Berl) 184:395-401.

Seki T, Arai Y (199lb) The persistent expression of a highly polysialylated NCAM in the dentate gyrus of the adult rat. Neurosci Res 12:503-513.

Stanfield BB, Trice JE (1988) Evidence that granule cells generated in the dentate gyrus of adult rats extend axonal projections. Exp Brain Res 72:399-406.

Sunshine J, Balak K, Rutishauser U, Jacobson M (1987) Changes in neural cell adhesion molecule (NCAM) structure during vertebrate neural development. Proc Natl Acad Sci USA 84:5986-5990.

Tang J, Landmesser L, Rutishauser U (1992) Polysialic acid influences specific pathfinding by avian motoneurons. Neuron 8:1031-1044.

Theodosis DT, Rougon G, Poulain DA (1991) Retention of embryonic features by an adult neuronal system capable of plasticity: polysialylated neural cell adhesion molecule in the hypothalamo-neurohypophysial system. Proc Natl Acad Sci USA 88:5494-5498.

Yang P, Yin X, Rutishauser U (1992) Intercellular space is affected by the polysialic acid content of NCAM. J Cell Biol 116:1487-1496. 